\title{
o-ヒドロキシアセトフェノン類の質量スペクトル
}

\section{Mass Spectra of Some o-Hydroxyacetophenones}

江口鎮子*·野田吉弘*·松尾昭彦* ·中山 充*

\author{
林 修一*
}

ShizUKo Eguchi, Yoshihiro Noda, AKiniko Matsuo, Mitsuru NaKayama

AND SHÛICHI HAYASHI

(1973年12月 6 日受理)

\begin{abstract}
Mass spectra of some $o$-hydroxyacetophenones were studied. The fragmentation is discussed on the basis of high resolution data and deuterium labeling. The resulting fragment patterns are clearly influenced by the position of the methoxy group.

It is shown that the significant structural information can be obtained from mass spectra of $o$-hydroxyacetophenones.
\end{abstract}

\section{1. 緒言}

天然から単離された酸素環式化合物の一群として, oーヒドロキシアセチルクロメン誘導体（例えばエボジ オノール $(\mathrm{I})^{1)}$, デスメチルエンセカリン (II $)^{2)}$, リパリオクロメン $\mathrm{A}^{3)}$ など）が知られている。著者ら はこれらの化合物の全合成を行ない，構造を確分した4)。 今回はこれらの化合物の孯監スペクトルを考察するた めに，モデル化合物として 0 -ヒドロキシアセトフェ<smiles>COc1c2c(cc(O)c1C(C)=O)OC(C)(C)C=C2</smiles><smiles>[R6]c1ccc(C(C)=O)c(O)c1</smiles><smiles>[R20]c1ccc(O)c(C(C)=O)c1</smiles>

$\begin{array}{ll}\text { N } & \mathrm{R}=\mathrm{CH}_{3} \\ \text { VII } & \mathrm{R}=\mathrm{CD} 3\end{array}$

V $\mathrm{R}=\mathrm{CH}_{3}$

Vill $\mathrm{R}=\mathrm{CD} 3$
II

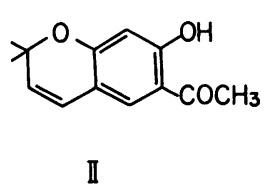

アセトフェノン（IN，V，VI）の篮量スペクトルを㭥 討したので報告する。

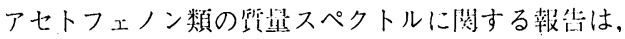
Meyersonの研究 5) や覞換アセトフェノン類の德換基 効雀の研究6) など数多く知られている7)。しかし,o-と ドロキシアセトフェノン類特にメトキシ基の位谓罳性 体相互の埧些スペクトルを比較した報告はみあたらな い。

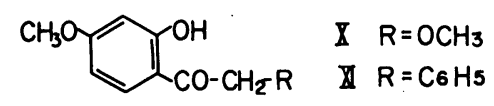

*広島大学理学部化学教空 (広島市東千田町)

Faculty of Science, Hiroshima University (Higashisenda-machi, Hiroshima, 730 Japan) 


\section{2. 実験}

\section{1 質量スペクトルの測定}

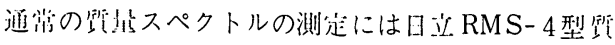

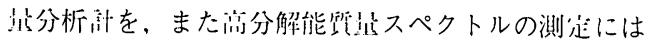

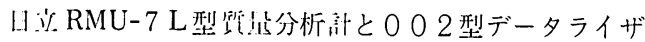
一のオンラインシステムをそれぞれ川いて测分した。 测定条俳はつぎのとおりである。

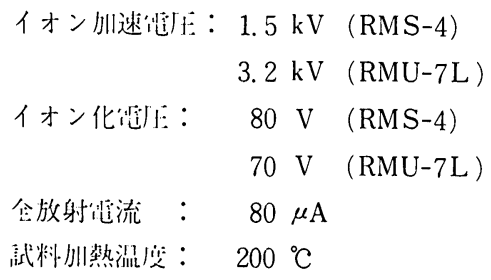

\section{2 試 料}

oーヒドロキシアセトフェノン類 $(\mathrm{N} \sim \mathrm{VI})$ はそれぞ れ文献记截の川泛で合成した。また，それぞれの可水
素メチルエーテル（ $(\mathbb{I} 〜 X)$ は机少するヒドロキシ体 から Merwe らの方汒 ${ }^{8)}$ またはアセトン中焱酸かリウ ムを維合郕とする沃化重メチルとの文志を川いて合成 した。

\section{3、結果および考察}

\section{$3.1 \quad o$-ヒドロキシアセトフェノン（III）の質量 スペクトル}

oーヒドロキシアセトフェノン（III）の筫证スペクト

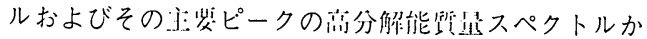
ら得られたエレメントテーブルをFig. 1 と Table 1 に 亦した。

アセトフェノンは分子・イオンからアセチル基のメチ ル其がメチルラジカル $\left({ }^{\cdot} \mathrm{CH}_{3}\right)$ として脱離することが

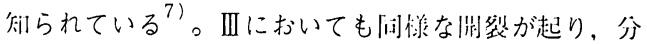
アイイン $\left(\mathrm{M}^{+}: m / e 136\right)$ からメチルラジカルが脱谯 した $m / e 121$ が梦準ピークとなり，引き絖き一酸化闵 菜 $(\mathrm{CO})$ が 2 吺脱離して $m / e$ 93 おうざ $m / e$ 65のピ

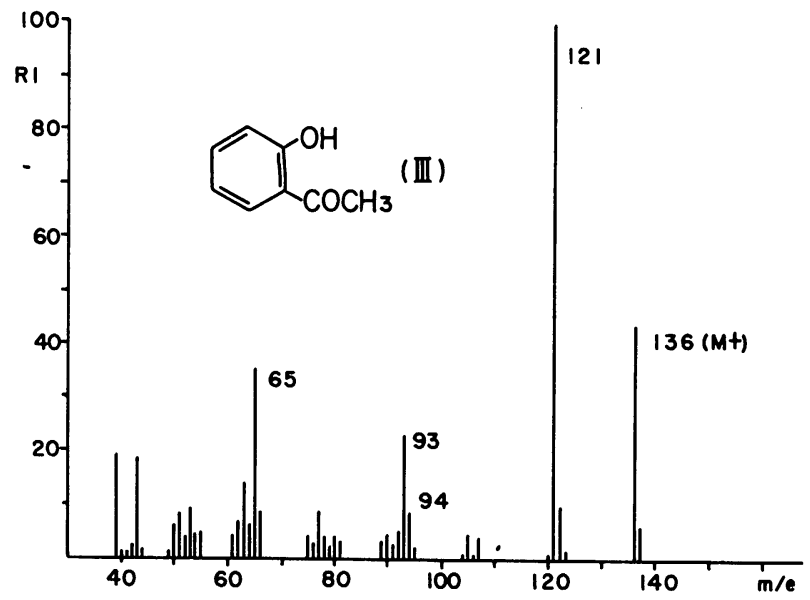

Fig. 1. Mass spectrum of 0 -hydroxyace tophenone (III).

Table 1. Element table of $o$-hydroxyacetophenone (III).

\begin{tabular}{|c|c|c|c|c|c|}
\hline Intensity & Element & & & $m / e$ (Obs.) & $m / e$ (Calc. ) \\
\hline 24 & $\mathrm{C}_{5} \mathrm{H}_{5}$ & \multirow{2}{*}{$-\mathrm{CO}$} & \multirow{5}{*}{$-\mathrm{CH}_{2}=\mathrm{C}=\mathrm{O}$} & $65: 0395$ & 65.0391 \\
\hline 17 & $\mathrm{C}_{6} \mathrm{H}_{5} \mathrm{O}_{1}$ & & & 93.0362 & 93.0340 \\
\hline 9 & $\mathrm{C}_{6} \mathrm{H}_{6} \mathrm{O}_{1}$ & $-\mathrm{CO}$ & & 94.0148 & 94.0418 \\
\hline 100 & $\mathrm{C}_{7} \mathrm{H}_{5} \mathrm{O}_{2}$ & \multirow{2}{*}{$-\mathrm{CH}_{3}$} & & 121.0283 & 121.0288 \\
\hline 51 & $\mathrm{C}_{8} \mathrm{H}_{8} \mathrm{O}_{2}$ & & & 136.0533 & 136.0524 \\
\hline
\end{tabular}


一クが生成する。四に阽倠なものとしては, メタステ ーブルイオンピークは観測されなかったが, 分けイオ ンからケテン $\left(\mathrm{CH}_{2}=\mathrm{C}=\mathrm{O}\right)$ の脱離した $m / e 94$ の ピークが観测された。四の主なフラグメンテーション をScheme 1 に示した。
3.2 2-ヒドロキシ -4-メトキシアセトフェノン

(IV) の質量スペクトル

四の 4 位にメトキシ基を 1 個もった2ーヒドロキシー 4-メトキシアセトフェノン（IV）の留具入ベクトル损 よび_i:な゚゚ークのエレメントテーブルをFig. 2 およ

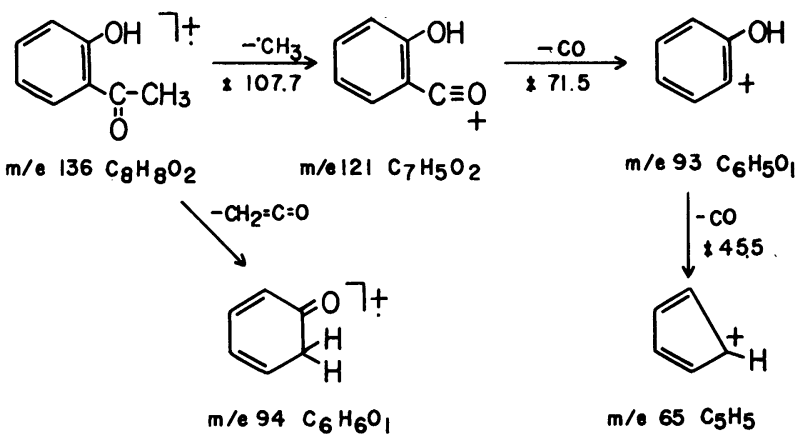

Scheme 1

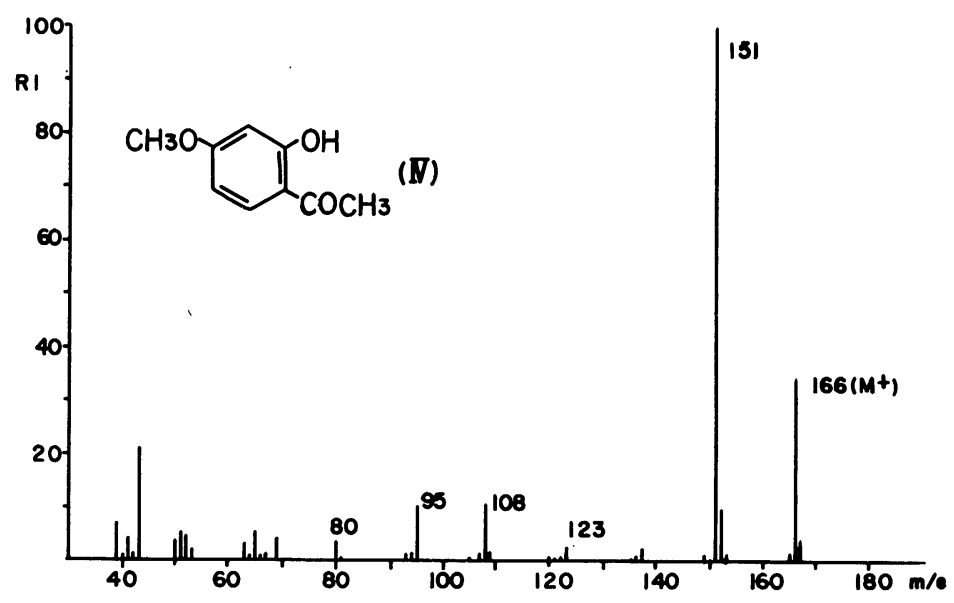

Fig. 2. Mass spectrum of 2-hydroxy-4-methoxyacetophenone (IV).

Table 2. Element table of 2-hydroxy-4-methoxyacetophenone (IV).

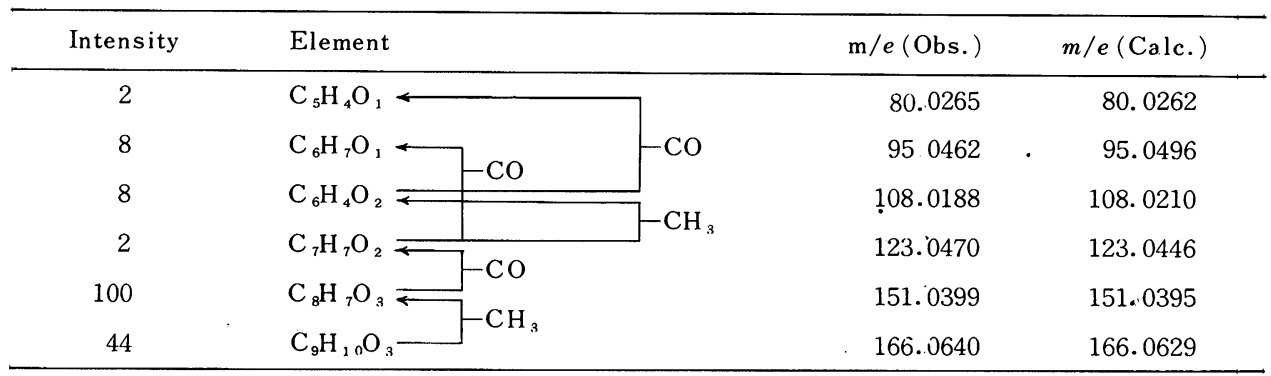


びTable 2に方した。

IVの啠赑スペクトルは四のそれと類似しているが,一 般にピークは小さい。基準ピークは分子イオン $(m / e 166$ $\left.: \mathrm{C}_{9} \mathrm{H}_{10} \mathrm{O}_{3}\right)$ からメチルラジカルの脱離した $m / e 151$ $\left(\mathrm{C}_{8} \mathrm{H}_{7} \mathrm{O}_{3}\right)$ である。このメチルラジカルがアセチル 基あるいはメトキシ基のいずれから脱離したかを明ら かにするため, IVの重水素メチルエーテル（VII）を合
成し比較検討した (Fig. 3, Table 3)。

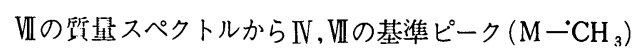
はアセチル基のメチルラジカルが脱離したものである ことがわかった。このことは, 2-ヒドロキシー4, ジメトキジャトフェノン（X) および2ーヒドロキシ -4-メトキシフェニルベンジルケトン (XI) に M$\mathrm{CH}_{3}$ のフラグメントイオンが在存しないことからも支

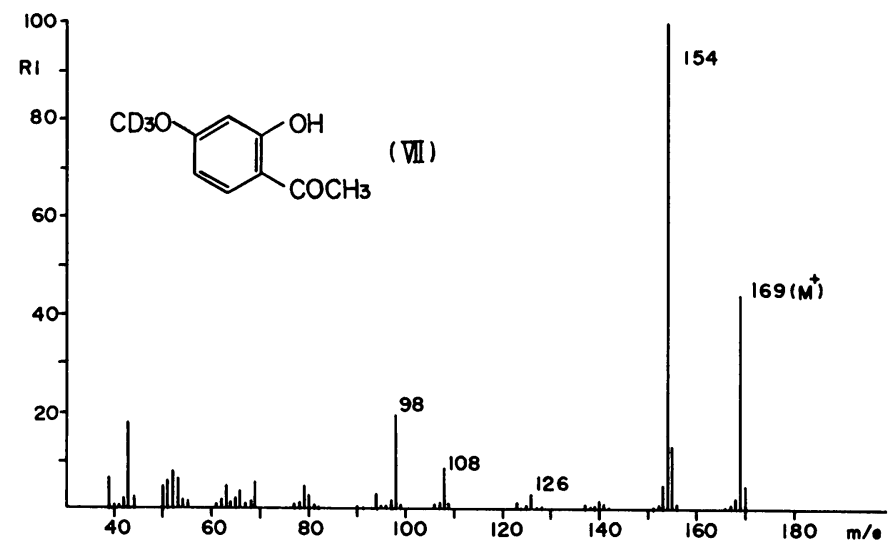

Fig. 3. Mass spectrum of 2-hydroxy-4-deuteromethoxyacetophenone (II).

Table 3. Element table of 2-hydroxy-4-deuteromethoxyacetophenone (VII).

\begin{tabular}{|c|c|c|c|}
\hline Intensity & Element & $m / e$ (Obs.) & $m / e($ Calc. $)$ \\
\hline 13 & $\mathrm{C}_{6} \mathrm{H}_{4} \mathrm{O}_{1} \mathrm{D}_{3} \longleftarrow$ & 98.0687 & 98.0685 \\
\hline 6 & $\mathrm{C}_{6} \mathrm{H}_{4} \mathrm{O}_{2} \hookleftarrow 4$ & 108.0208 & 108.0210 \\
\hline 3 & $\mathrm{C}_{7} \mathrm{H}_{4} \mathrm{O}_{2} \mathrm{D}_{3} \rightleftarrows-\mathrm{CO}$ & 126.0625 & 126.0634 \\
\hline 100 & $\mathrm{C}_{8} \mathrm{H}_{4} \mathrm{O}_{3} \mathrm{D}_{3} \rightleftharpoons-\mathrm{CO}$ & 154.0574 & 154.0582 \\
\hline 40 & $\mathrm{C}_{9} \mathrm{H}_{7} \mathrm{O}_{3} \mathrm{D}_{3}$ & 169.0822 & 169.0817 \\
\hline
\end{tabular}

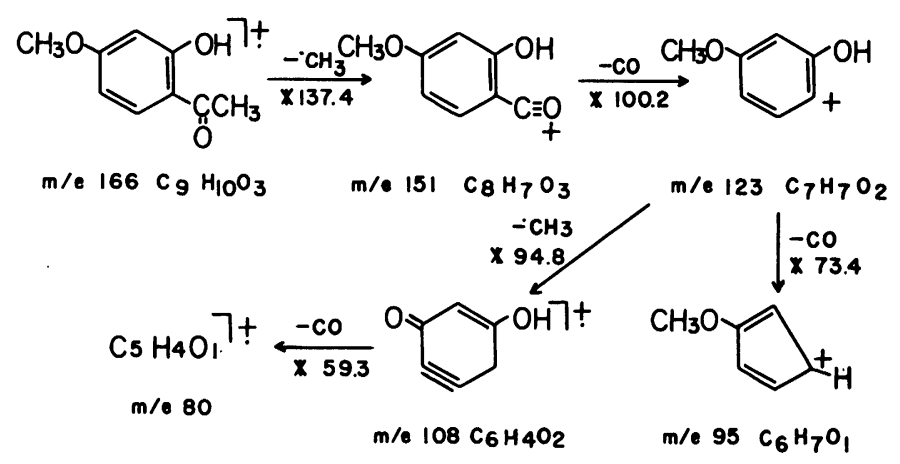

Scheme 2 
持される。基準ピークから，さらに四と同様に一酸化 炭素が引き続いて 2 回脱離して, IVでは $m / e ~ 123,95$,

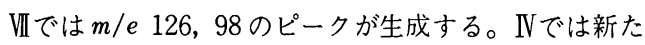
にm/e 123のイオンから4位のメトキシ基のメチルラ ジカルが脱離して $m / e$ 108, ついで一酸化炭素が脱離 して $m / e$ 80のピークを生成した。 $\mathrm{N} の$ 主なフラグメ ンテーションをScheme 2 に示した。

\subsection{2-ヒドロキシー5-メトキシアセトフェノン}

（V）の質量スペクトル

2-ヒドロキシー5ーメトキシアセトフェノン (V)の 質量スペクトルおよび主なピークのエレメントテーブ ルをFig 4 およびTable 4 に示した。

Vの睤量スペクトルには，IVと共通な m/e 166, 151, 123，108，95などのイオンピークの他に， m/e 148，
133，105 の特異なイオンピークか観測された。高分 解能スペクトルの測定結果から $m / e 148\left(\mathrm{C}_{9} \mathrm{H}_{8} \mathrm{O}_{2}\right)$ は 分子イオン $\left(m / e 166: \mathrm{C}_{9} \mathrm{H}_{10} \mathrm{O}_{3}\right)$ から水の脱離した ものであり， m/e $133\left(\mathrm{C}_{8} \mathrm{H}_{5} \mathrm{O}_{2}\right)$ は基準ピーク $(m / e$ $\left.151: \mathrm{C}_{8} \mathrm{H}_{7} \mathrm{O}_{3}\right)$ から水の脱離したピークである。 $m / e$ 151 のフラグメントイオンか観測されたことから，基 準ピーク（ $m / e$ 151）がアセチル基とメトキシ基のそ れぞれからメチルラジカルが脱離したイオンであるこ とを予測させる。これらの事実を明確にするために， $\mathrm{V}$ の重水素メチルエーテル（VIII）を合成し，その質量 スペクトルを測定した (Fig. 5, Table 5)。

VIIエレメントテーブルから， m/e 151のピークは 分子イオン $\left(m / e \quad 169: \mathrm{C}_{9} \mathrm{H}_{7} \mathrm{O}_{3} \mathrm{D}_{3}\right)$ から水が脱離 した $\mathrm{C}_{9} \mathrm{H}_{5} \mathrm{O}_{2} \mathrm{D}_{3}\left(\mathrm{M}-\mathrm{H}_{2} \mathrm{O}\right)$ と5.位のメトキシ基から

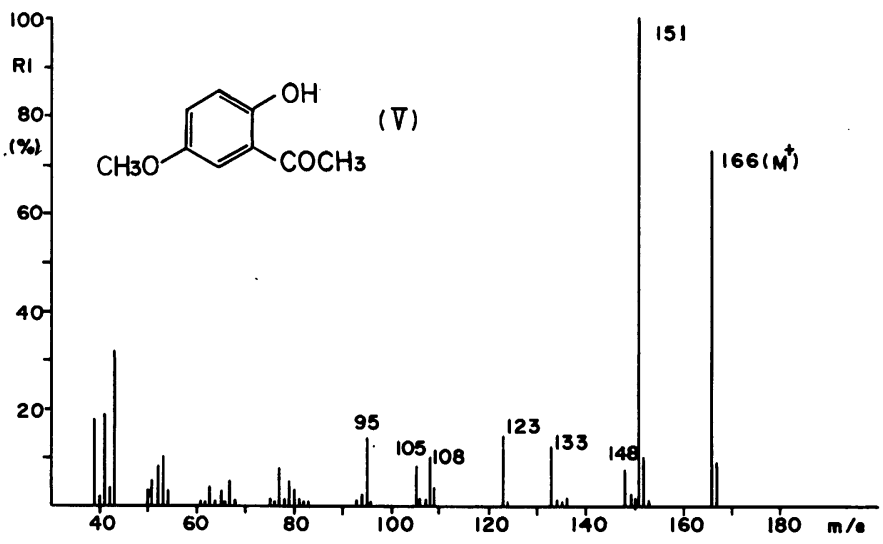

Fig. 4. Mass spectrum of 2-hydroxy-5-methoxyacetophenone (V).

Table 4. Element table of 2-hydroxy-5-methoxyacetophenone (V).

\begin{tabular}{|c|c|c|c|c|c|}
\hline Intensity & Element & & & $m / e$ (Obs.) & $m / e$ (Calc.) \\
\hline 12 & $\mathrm{C}_{6} \mathrm{H}_{7} \mathrm{O}_{1}$ & & \multirow{4}{*}{$-\mathrm{CO}$} & 95.0495 & 95.0495 \\
\hline 11 & $\mathrm{C}_{7} \mathrm{H}_{5} \mathrm{O}_{1}$ & & & 105.0349 & 105.0340 \\
\hline 12 & $\mathrm{C}_{6} \mathrm{H}_{4} \mathrm{O}_{2}$ & $-\mathrm{CO}$ & & 108.0226 & 108.0211 \\
\hline 13 & $\mathrm{C}_{7} \mathrm{H}_{7} \mathrm{O}_{2}$ & 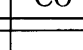 & & 123.0449 & 123.0455 \\
\hline 12 & $\mathrm{C}_{8} \mathrm{H}_{5} \mathrm{O}_{2}$ & $-H$ & \multirow{4}{*}{$-\mathrm{H}_{2} \mathrm{O}$} & 133. 0265 & 133. 0289 \\
\hline 5 & $\mathrm{C}_{9} \mathrm{H}_{8} \mathrm{O}_{2}$ & $-\mathrm{H}_{2}$ & & 148.0523 & 148.0523 \\
\hline 100 & $\mathrm{C}_{8} \mathrm{H}_{7} \mathrm{O}_{3}$ & $-\mathrm{CH}$ & & 151.0377 & 151.0394 \\
\hline 70 & $\mathrm{C}_{9} \mathrm{H}_{10} \mathrm{O}$ & $\mathrm{CH}_{3}$ & & 166.0655 & 166. 0629 \\
\hline
\end{tabular}




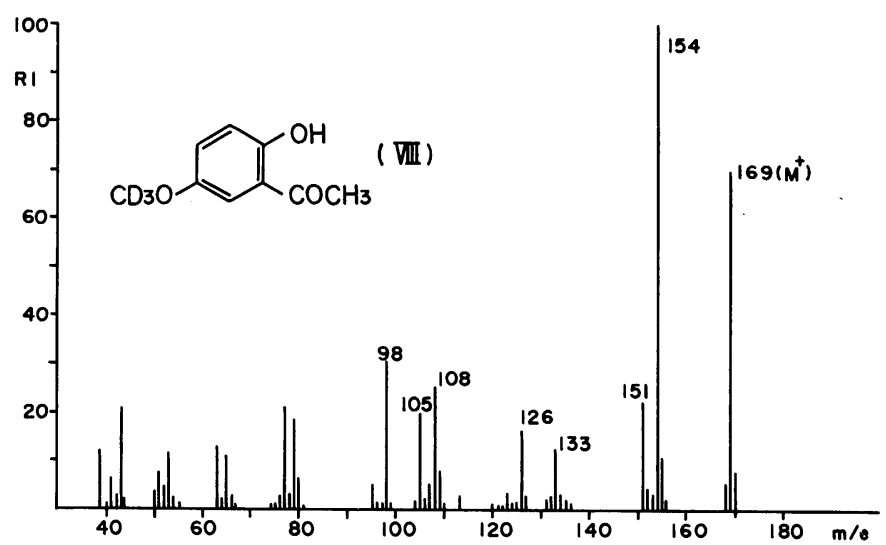

Fig. 5. Mass spectrum of 2-hydroxy-5-deuteromethoxyacetophenone (VII).

Table 5. Element table of 2-hydroxy-5-deuteromethoxyacetophenone (VII).

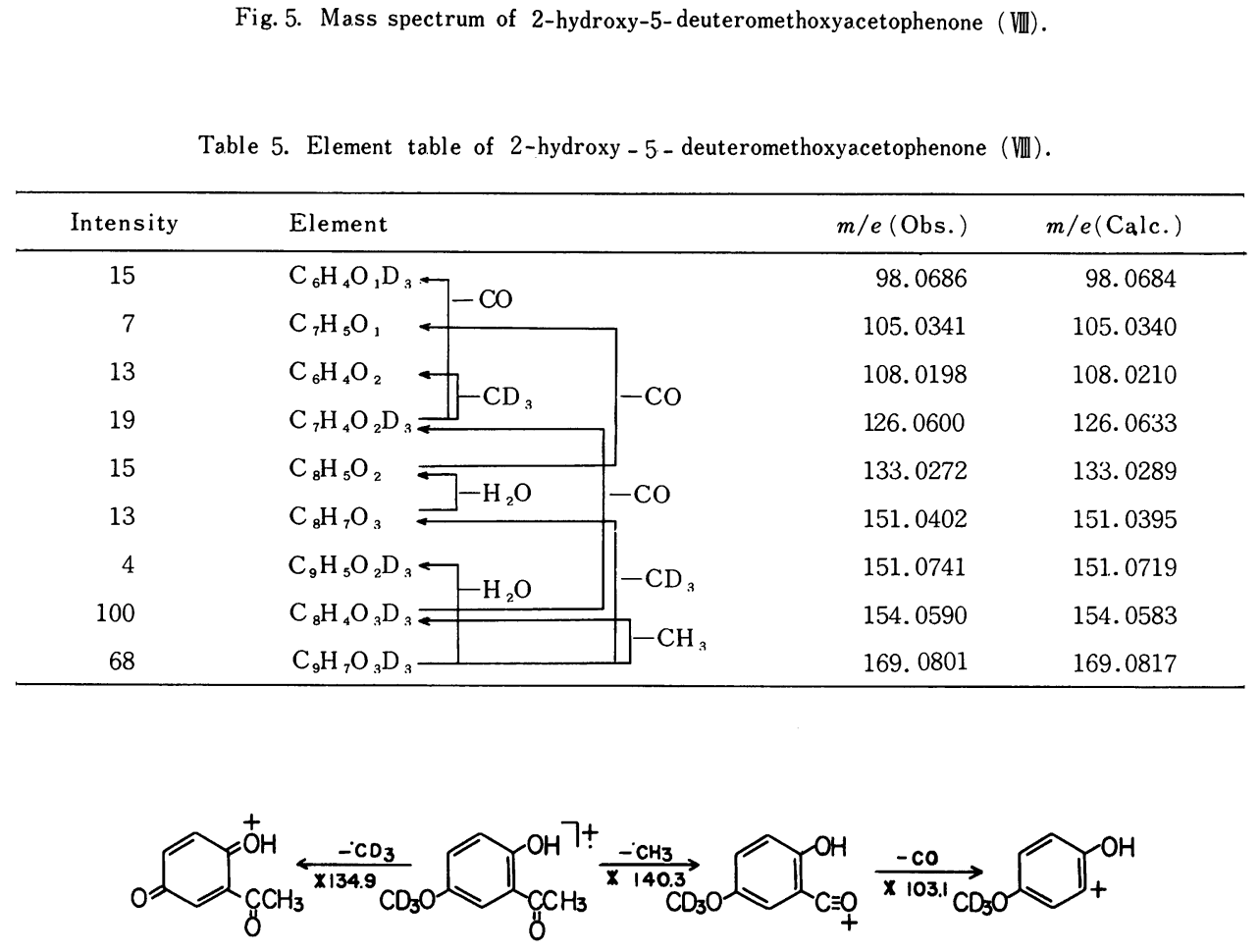
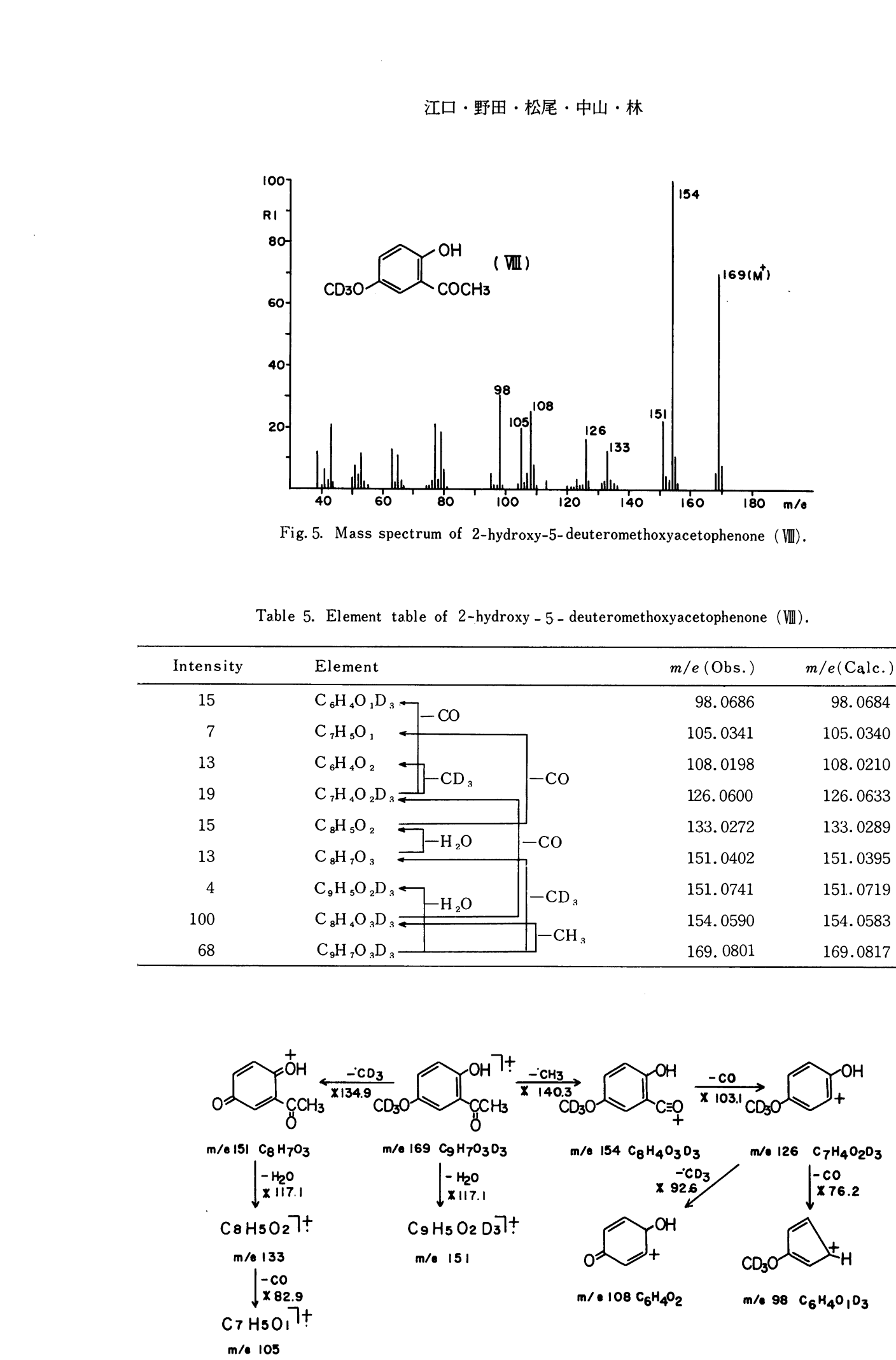

Scheme 3 
重メチルラジカルが脱離した $\mathrm{C}_{8} \mathrm{H}_{7} \mathrm{O}_{3}\left(\mathrm{M}-\mathrm{CD}_{3}\right)$ の二 重ピークであることが知られる。この結果，Vの基準 ピーク ( $m / e$ 151) は分子イオンのアセチル基からメ チルラジカルが脱離して生じたイオンと 5 位のメトキ シ基からメチルラジカルが脱離したイオンとが 100 : 13の割合で存在することがわかった。

さらに, 水の脱離によって生じた $m / e 151\left(\mathrm{C}_{9} \mathrm{H}_{5}\right.$ $\left.\mathrm{O}_{2} \mathrm{D}_{3}\right)$ および $m / e 133\left(\mathrm{C}_{8} \mathrm{H}_{5} \mathrm{O}_{2}\right)$ のピークは, とも にオルト位の水酸基とアセチル基との間で脱水してい ることが明らかである ${ }^{9)}$ 。その他, $m / e$ 133のピークか ら一酸化炭素が脱離して生じる $\mathrm{m} / \mathrm{e}$ 105のピークも観 測された。メタステーブルイオンピークの観測と合せ て，V，相のフラグメンテーションを考察し，怫のフ ラグメンテーションをScheme 3に示した。
3.4 2-ヒドロキシ -6-メトキシアセトフェノン

(VI) の質量スペクトル

2-ヒドロキシー6ーメトキシアセトフェノン（VI）の 質量不ペクトルおよび主なピークのエレメントテーブ ルをFig. 6およびTable 6に示した。

IV とVにおいては主要開裂が同一であったのに対し， メトキシ基がアセチル基に対してオルト位にあるVに おいては，これらとはやや異なった質量スペクトルを 与え，独自のフラグメンテーションを示している。特 に連続 2 回のメチルラジカルの脱離による $m / e 136$ $\left(\mathrm{C}_{7} \mathrm{H}_{4} \mathrm{O}_{3}\right)$ のイオンの生成は顕著で, この一連の開 裂には，相当するメタステーブルイオンもかなりの強 度で観測された。

第 1 段階がアセチル基からのメチル基の脱離による

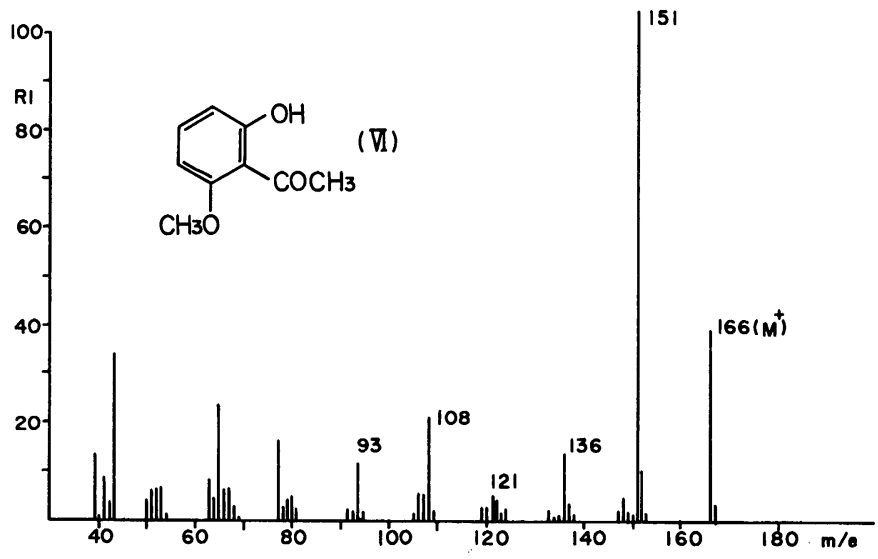

Fig. 6. Mass spectrum of 2-hydroxy-6-methoxyacetophenone (V).

Table 6. Element table of 2-hydroxy-6-methoxyacetophenone (VI).

\begin{tabular}{|c|c|c|c|c|c|}
\hline Intensity & Element & & & $m / e$ (Obs.) & $m / e$ (Calc.) \\
\hline 5 & $\mathrm{C}_{6} \mathrm{H}_{5} \mathrm{O}_{1}$ & \multirow{2}{*}{$-\mathrm{CO}$} & \multirow{3}{*}{$-\mathrm{CO}$} & 93.0361 & 93.0340 \\
\hline 19 & $\mathrm{C}_{6} \mathrm{H}_{4} \mathrm{O}_{2}$ & & & 108.0198 & 108.0211 \\
\hline 2 & $\mathrm{C}_{7} \mathrm{H}_{5} \mathrm{O}_{2}$ & \multirow{3}{*}{$-\mathrm{CH}_{3}$} & & 121.0314 & 121.0289 \\
\hline 17 & $\mathrm{C}_{7} \mathrm{H}_{4} \mathrm{O}_{3}$ & & \multirow[t]{3}{*}{$-\mathrm{CH}_{2} \mathrm{O}$} & 136.0159 & 136.0160 \\
\hline 100 & $\mathrm{C}_{8} \mathrm{H}_{7} \mathrm{O}_{3}$ & & & 151.0387 & 151.0394 \\
\hline 45 & $\mathrm{C}_{9} \mathrm{H}_{10} \mathrm{O}_{3}$ & $-\mathrm{CH}_{3}$ & & 166.0634 & 166.0629 \\
\hline
\end{tabular}




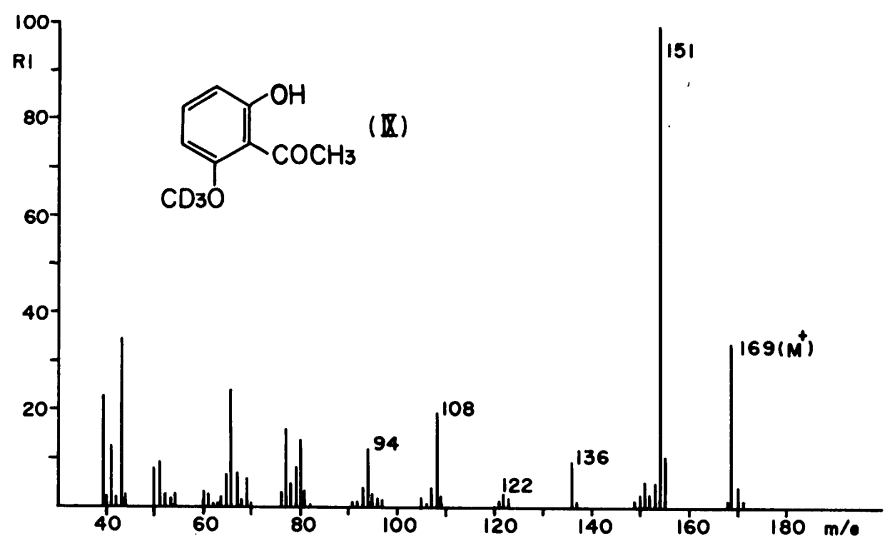

Fig. 7. Mass spectrum of 2-hydroxy-6- deuteromethoxyacetophenone (IX).

Table 7. Element table of 2-hydroxy-6- deuteromethoxyacetophenone (IX).

\begin{tabular}{|c|c|c|c|c|c|}
\hline Intensity & Element & & & $m / e$ (Obs.) & $m / e$ (Calc.) \\
\hline 5 & $\mathrm{C}_{6} \mathrm{H}_{4} \mathrm{O}_{1} \mathrm{D}_{1}$ & & \multirow{3}{*}{$-\mathrm{CO}$} & 94.0395 & 94.0402 \\
\hline 13 & $\mathrm{C}_{6} \mathrm{H}_{4} \mathrm{O}_{2}$ & $-\mathrm{CO}$ & & 108.0181 & 108. 0210 \\
\hline 2 & $\mathrm{C}_{7} \mathrm{H}_{4} \mathrm{O}_{2} \mathrm{D}_{1}$ & 100 & & 122.0377 & 122.0352 \\
\hline 11 & $\mathrm{C}_{7} \mathrm{H}_{4} \mathrm{O}_{3}$ & \multirow{2}{*}{$-\mathrm{CD}_{3}$} & \multirow[t]{4}{*}{$-\mathrm{CD}_{2} \mathrm{O}$} & 136.0140 & 136.0160 \\
\hline 3 & $\mathrm{C}_{9} \mathrm{H}_{5} \mathrm{C}_{2} \mathrm{D}_{3}$ & & & 151.0684 & 151.0712 \\
\hline 100 & $\mathrm{C}_{8} \mathrm{H}_{4} \mathrm{O}_{3} \mathrm{D}_{3}$ & \multirow{2}{*}{$-\mathrm{CH}_{3}$} & & 154.0560 & 154.0582 \\
\hline 39 & $\mathrm{C}_{9} \mathrm{H}_{7} \mathrm{O}_{3} \mathrm{D}_{3}$ & & & 169.0831 & 156.0818 \\
\hline
\end{tabular}

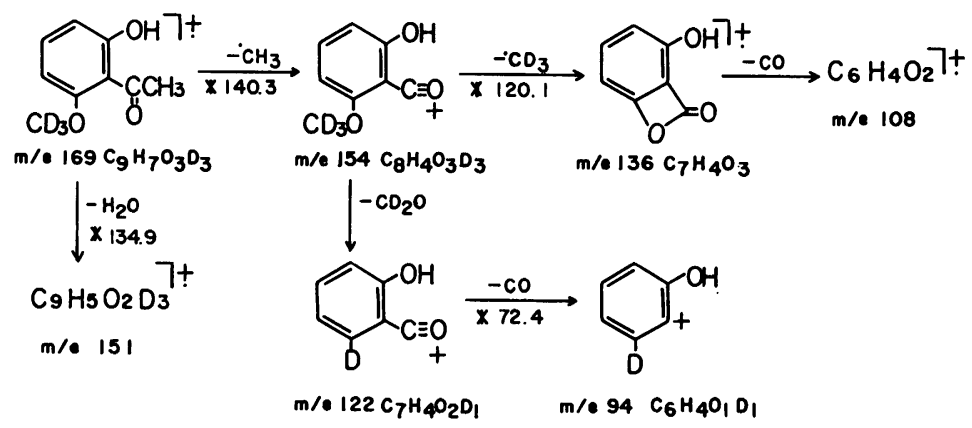

Scheme 4 
ことは, $m / e 151\left(\mathrm{C}_{8} \mathrm{H}_{7} \mathrm{O}_{3}\right)$ からホルマリン $\left(\mathrm{CH}_{2} \mathrm{O}\right)$ が脱離して $m / e$ l $121\left(\mathrm{C}_{7} \mathrm{H}_{5} \mathrm{O}_{2}\right)$ が生成していること からも容易に推察できる。また， $m / e$ 151が Vの場合 と異なりアセチル基からのメチル基の脱離にもとづく ことも, $\left(\mathrm{M}-\mathrm{C}_{3}-\mathrm{H}_{2} \mathrm{O}\right)$ に相当する $m / e$ 133のピーク がないことからも推察される。これらの推察を確認す るために、Vの重水素メチルエーテル（IX）を合成し， その質量スペクトルを測定した。

XX゙は分子イオン $\left(\mathrm{m} / \mathrm{e} 169: \mathrm{C}_{9} \mathrm{H}_{7} \mathrm{O}_{3} \mathrm{D}_{3}\right)$ のア七チ ル基からメチルラジカルが脱離して, 先ず $m / e 154$

$\left(\mathrm{C}_{8} \mathrm{H}_{4} \mathrm{O}_{3} \mathrm{D}_{3}\right)$ を生成することがエレメントテーブル の考察から明らかとなり,つづいて重メトキシ基の重 メチルラジカル $\left({ }^{\circ} \mathrm{CD}_{3}\right)$ が脱離して $/$ /e $136\left(\mathrm{C}_{7} \mathrm{H}_{4} \mathrm{O}_{3}\right)$ のピークを生成することもメタステーブルイオンピー ク $\left(m^{*}: 113.6\right)$ の観測から明らかとなった。 $m / \mathrm{e} 136$ は次に一酸化炭素を脱離して m/e $108\left(\mathrm{C}_{6} \mathrm{H}_{4} \mathrm{O}_{2}\right)$ とな る。

一方, 机における $m / e 121\left(\mathrm{C}_{7} \mathrm{H}_{5} \mathrm{O}_{2}\right)$ のピークは, IXに扩ける $m / e 122\left(\mathrm{C}_{7} \mathrm{H}_{4} \mathrm{O}_{2} \mathrm{D}_{1}\right)$ と同様に, 基準ピ ークの6位のメトキシ基から重ホルマリン $\left(\mathrm{CD}_{2} \mathrm{O}\right)$ が 脱離して生成することが明らかである。関係するメ タステーブルイオンの観測はできなかったが、この開 裂は含メトキシ基化合物にはよくみられるものである ${ }^{10) 。 ~}$ $m / e 122$ からさらに一酸化炭素が脱離した $m / e 94$ $\left(\mathrm{C}_{6} \mathrm{H}_{4} \mathrm{O}_{1} \mathrm{D}_{1}\right)$ のピークはメタステーブルイオンピー クと共に観測された。また，小さいながら V と同怑に 分子イオンから直接水の脱離した $m / e \quad 151\left(\mathrm{C}_{9} \mathrm{H}_{5} \mathrm{O}_{2} \mathrm{D}_{3}\right)$ のピークも観測された。以上の結果から、IXの主なフ ラグメンテーションをScheme 4 にまとめた。

\section{4. 結語}

モノメトキシーoーヒドロキシアセトフェノン類は類 似した質量スペクトルを示した。しかし, 重水素メチ ルエーテルを合成して, 個々のフラグメンテーション を検討したところ、メトキシ基の置換位置によりフラ グメンテーションにかなりの差異があることが明らか になった。天然産oーヒドロキシアセチルクロメン誘導 体の構造決定に，質量スペクトルは十分利用できる。 今後さらに,ポリメトキシ置換誘導体およびクロメン 誘導体について検討し，天然産o-ヒドロキシアセチル クロメン誘導体の質量スペクトルの解析を試みたい。

\section{文献}

1) F.M. Dean, "Naturally Occurring Oxygen Ring Compounds", Butterworths Press, London (1963), p .224 .

2) F. Bohlmann and M. Grenz, Chem. Ber., 103,90(1970).

3 ) T. Anthonsen, Acta Chem. Scand., 23, 3605(1969).

4) a) 中山 充・西村新二・松井隆尚・林 修一・福井憲 二, 日化, 91, 1174(1970).

b)M. Nakayama, M.Ohno, S. Hayashi and K. Fukui, Bull. Chem. Soc. Japan, 43, 3371(1970).

c)M. Nakayama, S. Hayashi, M. Tsukayama, T. Horie and M. Masumura, Chem. Lett., 1972, 315.

5 ) S. Meyerson and P. N. Rylander, J.Am. Chem. Soc., 79. 1058(1957).

$6)$ M. S. Chin and A. G. Harrison, Org. Mass Spectrom., 2. 1073(1969).

7 ) D. H.Williams, Senior Reporter, "Mass Spectrome try", Vol.1, The Chemical Society, Burlington House, London (1971), p. 108 .

8 ) K. J. Van der Merwe, P. S. Steyn and S. H. Eggers, Teträhedron Lett., 1964, 3923.

9 ) 中山 充·江口鎮子・松尾昭彦・林 修一, 未発表.

10）中山 充·江口鎮子 - 松尾昭彦 - 林 修一・菱田真三 郎·加藤義昭, 睤量分析, 20,89(1972). 